\title{
Perkembangan Obat Sariawan dan Terapi Alternatifnya
}

\author{
Prilly Mutiara Sandy*, Fira Burhanisa Irawan \\ Program Studi Sarjana Farmasi, Fakultas Farmasi, Universitas Padjadjaran, Sumedang 45363 \\ email: prillymutiaras@gmail.com
}

\begin{abstract}
Abstrak :
Sariawan merupakan penyakit mulut yang sudah tidak asing lagi. Berbagai kalangan mulai dari balita, remaja, orang tua, maupun lanjut usia tentu pernah mengalami penyakit tersebut. Efek dari sariawan itu sendiri ialah bisa menyebabkan para penderitanya tidak nafsu makan dan mulut terasa perih. Pengobatan yang dapat dilakukan adalah dengan mengonsumsi zat pemati rasa dan antiseptika.Pemakaiannya obat bisa dilakukan sebanyak 2-3 kali dalam sehari. Selain dengan zat pemati rasa, sariawan juga dapat diobati dengan antiseptika. Hasil terbaik dari penggunaan antiseptika terbukti oleh obat kumur provid-ion (Betadine) dan klorheksidin dalam bentuk tablet hisap srta larutan peroksida 3\%. Selain itu juga bisa menggunakan obat kumur yang mengandung Chlorhexidine gluconate $2 \%$, sodium hyaluronate, PVP, dan glycyrrhetinic. BPOM menganjurkan penggunaan obat-obat yang memiliki kandungan enzydamine $\mathrm{HCL}$, providone iodine $1 \%$, atau kombinasi dequalinium chloride dan vitamin C. Bagi yang ingin menyembuhkan sariawan dengan bahan-bahan alami, yaitu: tanaman gambir, daun sirih, air garam, dan cabai.
\end{abstract}

Keyword : obat, sariawan, terapi alternative

\section{Outline}

- Pendahuluan

- Terapi sariawan

- Albothyl (policresulen)

- Terapi alternatif

- Kesimpulan

\section{Pendahuluan}

Sariawan atau aphtous stomatitis adalah luka yang terdapat di dalam mulut yang biasanya berbentuk oval atau bulat berwarna putih dan dapat menimbulkan rasa tidak sakit serta tidak nyaman.

Sariawan disebabkan oleh beberapa hal, diantaranya ialah kurangnya vit C, vit B12 dan bisa juga karena adanya infeksi yang disebabkan oleh bakteri, virus, atau jamur. Selain itu, sariawan juga dapat disebabkan oleh luka pada mulut akibat tergigit atau mengkonsumsi sesuatu yang keras atau tajam. Luka - luka kecil tersebut menjadi sasaran empuk bagi bakteri mulut dan menimbulkan suatu reaksi imun tertenu (Autoimun). 
Perubahan kadar hormon yang biasanya dialami oleh wanita pada saat siklus haid juga menyebabkan timbulnya sariawan. Biasanya, pada sariawan muncul pada saat kurang lebih 7 hari sebelum haid. Sariawan tentunya dapat dicegah yaitu dengan memakan makanan atau buah yang mengandung banyak vitamin $C$, seperti jeruk, tomat, dan lain - lain.

\section{Terapi Sariawan}

Pengobatan yang dapat dilakukan adalah dengan mengonsumsi zat pemati rasa dan antiseptika. Zat pemati rasa yang digunakan adalah lidokain yang tersedia dalam berbagai sediaan, seperti tablet bisap, spray, obat kumur maupun salep. Cara pemakaianya adalah dengan meneteskan obat tersebut ke kassa atau kapas lalu ditempelkan ke bagian mulut yang terdapat sariawannya.

Pemakaiannya obat bisa dilakukan sebanyak 2-3 kali dalam sehari. Selain dengan zat pemati rasa, sariawan juga dapat diobati dengan antiseptika. Hasil terbaik dari penggunaan antiseptika terbukti oleh obat kumur provid-ion (Betadine) dan klorheksidin dalam bentuk tablet hisap srta larutan peroksida $3 \%$. . Selain itu juga bisa menggunakan obat kumur yang mengandung Chlorhexidine gluconate $2 \%$, sodium hyaluronate, PVP , dan glycyrrhetinic.

\section{Albothyl (policresulen)}

Selain obat kumur yang telah disebutkan diatas, terdapat pula obat sariawan lain yang paling sering digunakan dikalangan masyarakat, yakni albothyl. Karena asumsi dan harapan masyarakat tentang obat ini akan menyembuhkan sariawan hampir secara instan. Namun, apakah kalian tahu apa saja yang terkandung di dalam albothyl?

Albothyl adalah nama dagang untuk senyawa policresulen dan salah satu jenis obat antiseptik dan disinfektan kulit. Obat ini merupakan proses kondensasi dari metacresolsulfonic acid dan methanal. Policresulen biasanya digunakan untuk menghentikan perdarahan lokal (hemostatik lokal). Policresulen merupakan senyawa produk kondensasi metacresolsulfonic acid dan methanal.

Sementara, suatu obat tidak boleh dipergunakan sebagai hemostatik dan antiseptik ketika saat pembedahan serta penggunaan pada tenggorokan;sariawan; ataupun gigi. Hal ini pun menunjukkan bahwa tujuan penggunaan albothyl yang seharusnya adalah bukan sariawan, melainkan untuk kelainan pada kulit (anus dan vagina). Mukosa kulit, secara anatomi jaringannya sedikit berbeda dengan mukosa mulut.perbedaan struktur ini juga mengindikasikan bahwa obat yang seharusnya dipakai ke dalam mulut itu berbeda dengan obat kulit lainnya.

Salah satu kegunaan policresulen adalah untuk membakar jaringan sehingga pendarahannya berhenti. Secara tidak langsung, dapat dikatakan jika policresulen dibubuhkan diatas sariawan dapat mematikan jaringan mulut tersebut, hal ini diyakinkan dengan adanya laporan dari masyarakat yang menderita efek samping dari policresulen ini. 
Ketua Ikatan Spesialis Penyakit Mulut Indonesia (ISPMI) ini juga menjelaskan, policresulen mungkin bisa digunakan untuk tujuan tersebut pada bagian tubuh lain, kecuali mulut. Karena $\mathrm{pH}$ pada policresulen tersebut sangat rendah dan jika digunakan pada mulut akan mengalami nekrosis atau kematian jaringan. Lalu, bagaimana jika albothyl dipakai ke dalam mulut penderita sariawan dalam jumlah yang melebihi dosis? Karena keinginan akan lepas dari sariawan ini yang notabenenya sangat menggangu, padahal penggunaan dalam dosis kecil kedalam mulut sudah berbahaya.

BPOM RI telah menerima 38 laporan dari profesional kesehatan mengenai efek samping yang ditimbulkan akibat penggunaan albothyl. Efek samping yang ditimbulkan diantaranya sariawan membesar dan berlubang hingga menimbulkan infeksi (noma like lession). Hal ini membuktikan bahwa pemakaian albothyl tidak diperuntukkan untuk penyakit sariawan melainkan penyakit yang lain. Albothyl mungkin bisa digunakan sebagai obat sariawan tetapi pada penggunaannya harus dicampurkan dengan air terlebih dahulu agar konsentrasi dari obat tersebut tidak terlalu pekat dan akan terencerkan jika ditambah air terlebih dahulu.

Kandungan policresulen dalam albothyl memberikan banyak efek samping. Kandungan policresulen yang diduga dapat menyembuhkan sariawan malah berdampak buruk karena pada akhirnya sel menjadi mati sehingga tidak terasa sakit.

Cara kerja dari policresulen sendiri ialah mematikan sel-sel dengan cara penyempitan pembuluh darah kapiler sehingga sel menjadi mati dan tidak dapat suplai darah. Pada saat sel mati, tubuh kita berfungsi untuk melakukan regenerasi sel. Namun, apabila tubuh kita tidak mampu melakukan hal tersebut, maka akan memberikan efek yang lebih parah lagi, yaitu infeksi malah menyebar dan bisa menyebabkan kematian.

\section{Terapi alternatif}

Oleh karena itu, Persatuan Dokter Gigi Indonesia (PDGI) memberikan anjuran untuk mengonsumsi vitamin $\mathrm{A}$ dan vitamin $\mathrm{C}$ terlebih dahulu untuk memperbaiki luka sariawan dengan menambah kekuatan sistem imun. Setelah itu, menggunakan obat kumur yang mengandung aloe vera atau oksigen yang akan mempercepat proses metabolisme secara alami supaya luka dimulut dapat lekas sembuh. Sedangkan BPOM menganjurkan penggunaan obat-obat yang memiliki kandungan enzydamine $\mathrm{HCL}$, providone iodine $1 \%$, atau kombinasi dequalinium chloride dan vitamin $\mathrm{C}$. Bagi yang ingin menyembuhkan sariawan dengan bahan-bahan alami, yaitu: tanaman gambir, daun sirih, air garam, dan cabai.

Tanaman gambir sejak dulu sudah dikenal memiliki manfaat obat dan dipercaya sebagai obat cuci luka bakar, kudis, diare dan disentri, obat kumur-kumur untuk sakit tenggorokan dan sariawan karena kandungan antibakteri yang berasal dari senyawa flavonoid dari tanaman ini. Cara memakan tumbuhan ini untuk obat sariawan adalah dengan mengunyahnya. Gambir memiliki rasa khas pahit dan kelat, tapi setelah lama dikunyah menjadi manis. 
Salah satu manfaat daun sirih adalah dapat meredakan nyeri dan menyembuhkan sariawan. Daun sirih mengandung zat antiseptik yang bisa menekan tumbuhnya bakteri dan jamur. Menurut penelitian yang dilakukan dan jurnal sains yang ada, dengan membuat air rebusan daun sirih kemudian dikumurkan di mulut, akan efektif mengobati sariawan. Khasiat daun sirih ini secara empiris diturunkan melalui masyarakat zaman dahulu dan diturunkan hingga sekarang.

Garam adalah bahan baku yang sangat mudah untuk dicari, jika kedua bahan diatas jarang bisa ditemukan, maka pergunakanlah garam sebagai solusinya. Garam dapat semacam membersihkan area sariawan, sehingga membantu proses penyembuhan dan menghilangkan rasa nyeri untuk sementara. Cara mempergunakannya adala dengan cara melarutkannya ke dalam air kemudian dikumur. Larutan garam ini juga dapat digunakan sebagai obat nyeri gigi ataupun gusi.

Yang terakhir adalah cabai. Cabai dapat digunakan untuk sariawan Karen a kandungan vitamin $C$ nya yang lumayan tinggi. Cara memakainya adalah dengan mengambil air yang terdapat didalam buah cabai kemudian diberi ke tempat sariawan tersebut. Efek terapi yang dihasilkan lumayan cepat meskipun dalam pemakaiannya sangat perih. Namun, cara ini merupakan cara yang sebagian besar orang melakukannya karena mudah dan cepat.

\section{Kesimpulan}

Dengan menggunakan bahan alami seperti di atas, sariawan akan terobati tanpa harus menanggung efek sampingnya. Meskipun lebih lama menyembuhkan sariawan, namun cara yang alami seperti inilah yang paling aman digunakan.

\section{Daftar Pustaka}

Rahardja,K. dan H.T. Tan. 2010. Obat-obat Sederhana untuk Gangguan Sehari-hari. Jakarta : PT. Elex Media Komputindo

Taufik Ismail, Choirul Arifin. BPOM: Efek Samping Penggunaan Albothyl Bisa Sebabkan Infeksi, https://www.tribunnews.com/kesehatan/2018/02/16/bpom-efek-sampingpenggunaan-albothyl-bisa-sebabkan-infeksi.

Frieda Isyana Putri. Albothyl Dilarang, Ini Saran PDGI untuk Obati Sariawan. https://health.detik.com/berita-detikhealth/d-3870218/albothyl-dilarang-ini-saran-pdgiuntuk-obati-sariawan.

Widiya Wiyanti. Albothyl Dilarang, Ini Pilihan Pembaca untuk Sembuhkan Sariawan. https://health.detik.com/berita-detikhealth/3871296/albothyl-dilarang-ini-pilihan-pembacauntuk-sembuhkan-sariawan 